\title{
Contamination Rates by Delivery Method of Human Umbilical Cord Blood Samples in the United Arab Emirates and Gulf Co- operation Council Countries
}

\author{
Mai Ibrahim $^{1^{*}(\mathbb{D}) \text {, Sarah AL-Hajali }}{ }^{1}$, Mona Abdelmeguid ${ }^{2}$ and Saad Aswad ${ }^{3}$ \\ ${ }^{1}$ CellSave, Dubai Healthcare City, United Arab Emirates \\ ${ }^{2}$ Center for Molecular Nutrition and Sensory Disorders, Washington DC, USA
}

${ }^{3}$ Al Tawam Hospital, United Arab Emirates

*Corresponding author: Mai Ibrahim, CellSave, Dubai Healthcare City, Dubai, United Arab Emirates

\begin{abstract}
The use of umbilical cord blood, which is recognized as a rich source of hematopoietic stem cells, has become an alternative source to bone marrow for transplantation. Cord blood units used for transplant might be rejected due to positive bacterial microbiology. According to common cell therapy standards a microbiology bacterial identification is required to know the type of Bacteria, and to determine if the bacteria is considered critical or non-critical prior to the transplant determination. The aim of this study is to find the frequency and distribution of bacterial organisms among cord blood samples collected in the United Arab Emirates (UAE) and Gulf Cooperation Countries (GCC) and to investigate if there is a correlation with contamination rates between the delivery method, cesarean section or vaginal delivery. We employed a survey to healthcare professionals in order to augment the data and then employed statistical analysis in order to find the frequency of contamination and create best practices to avoid high level of contamination.
\end{abstract}

\section{Introduction}

Previously, umbilical cord and the placenta were considered biological waste and were discarded after birth. Cord blood is the blood in the baby's umbilical cord. It contains the stem cells, which are known for growing blood vessels, tissues and organs. The cord cells preservation has gained popularity in past few years as research has shown that, the stem cells are capable of growing many critical organs which can be used to treat various serious illnesses like cancer or organ failures [1-4].
The methods of storing, preserving and utilizing stem cells are being constantly researched and refined. The stem cells responsible for the development of blood (also known as "invulnerable cells") are hematopoietic stem cells (HSCs). Hematopoietic stem cells are cells isolated from the cord blood or bone marrow that can renew themselves and differentiate into a variety of specialized cells. Different cord blood collection, processing and sterilization techniques can lead to bacterial contamination. The bacterial contamination of blood components is a frequent challenge in transfusion medicine [5-11]. Bone marrow is still the traditional source of obtaining hematopoietic stem cells. However, bacterial contamination of hematopoietic stem cells obtained from cord blood can be a possible cause of rejection of a transplant unit.

\section{C-Section and Vaginal Cord Blood Collection Method}

Cord blood collection is a fairly simple, painless and a fast procedure that is performed during the delivery process. The cord blood samples can be collected during Vaginal or Caesarian delivery. There are two methods of collection. The method of collection is either In-utero, or ex-utero collection [9].

- In-Utero collection method: Collection of cord blood when the placenta is still attached to the mother's uterus.

\footnotetext{
Citation: Ibrahim M, AL-Hajali S, Abdelmeguid M, Aswad S (2020) Contamination Rates by Delivery
Method of Human Umbilical Cord Blood Samples in the United Arab Emirates and Gulf Cooperation Council Countries. Int J Stem Cell Res Ther 7:067. doi.org/10.23937/2469-570X/1410067

Accepted: April 13, 2020: Published: April 15, 2020

Copyright: (c) $2020 \mathrm{Ibrahim} \mathrm{M}$, et al. This is an open-access article distributed under the terms of the Creative Commons Attribution License, which permits unrestricted use, distribution, and reproduction in any medium, provided the original author and source are credited.
} 
- Ex-Utero collection method: Collection of cord blood from the cord and placenta after expulsion from the uterus.

Cord blood collection is initiated by double-clamping and then cutting the umbilical cord. The physician or nurse then snaps down the plastic needle guard around the collection tubing. After delivery of the baby(s), the umbilical cord is disinfected with disinfectant wipe at the needle insertion (collection) site. Then the cord blood is collected.

The cord blood unit then is received to the lab to be processed, tested and cryogenically stored under -197 ${ }^{\circ} \mathrm{C}$.

The aim of this study to investigate the contamination rate related to the delivery method, C-section versus vaginal delivery. To find the frequency and distribution of the bacterial organisms among UAE emirates and GCC countries.

\section{Materials and Methods}

We retrospectively reviewed the collection data of 1,250 samples between the period of 2013 and 2014. Variables included the delivery method (C-section or Vaginal), baby's condition, Baby's gender. We investigated the delivery method and its impact on the bacterial contamination rate received from the United Arab Emirates and other GCC countries.

This study has been used to analyze the frequency of contamination based on the historical data and also to find out the major bacterial contamination recorded by the hospitals. The collection records of total 597 samples were reviewed for the delivery method, baby's condition, and sample origin, and the results were normal.

The microbiological studies were performed with both types of automated systems Bactec technology for samples collected from UAE, and (BacT/Alert, bioMérieux Corporate) technology is used for sample collected from GCC countries. The aerobic and anerobic bottles were forwarded to a reference lab. If the bottle was positive, bacterial identification and sensitivity are automatically performed. The bottles are inoculated using $5 \mathrm{ml}$ of blood to each bottle, the blood is taken from the waste blood (after the stem cell extraction) before the addition of DMSO. The incubation period of Aerobic and Anerobic bottles was 5 days. The fungal test for sample collected from UAE and GCC are performed by using the SDA plate, and the incubation time is 14 days.

\section{Results}

Cord blood products between the year 2013 and 2014 were retrospectively analyzed to determine the contamination rate incidence. 1,250 samples data were recorded and analyzed. There was no difference in the samples weight, viability, Post TNC, and Total CD34 cells of the $\mathrm{C}$-section compared to the vaginal delivery.

Cord blood product of a period of 4 years between 2011-2014 was retrospectively analyzed to identify the type of the main organisms that cause contamination and the delivery method used.

From the total of 1,250 collections inside the UAE and GCC, there were a total of 768 vaginal collection, and the number of contaminated samples were $70(9 \%)$. There was a total of 482 cases of C-section collections, and the number of contaminated cases were 8 cases only (1.7\%) (Table 1).

\section{Contamination Rate and Distribution among the Emirates and GCC Countries}

The total number of contaminated samples was 78 samples, 70 contaminated samples were collected vaginally $(90 \%)$, and only 8 contaminated cases were collected by C-section (10\%) (Figure 1). We can see from the data that total C-section contamination rate was lower than $1 \%$ when taken from the total number of samples and that of vaginal contamination rate was about $6 \%$ when taken from the total samples (Figure 2). Hence, assuming we can see that vaginal delivery has a contaminate rates of 6 times more than C-section. Therefore, we can clearly see that Vaginal collection method is associated with higher contamination rate.

Therefore, the type of cord blood collection method is responsible for the contamination.

Using Chi-square, the association between the contamination of C-section compared to vaginal collection is extremely statistically significant with Fisher's exact

Table 1: Contamination rate of vaginal and C-section delivery.

\begin{tabular}{|l|l|}
\hline Total Samples & 1250 \\
\hline Total \# of positives & 78 \\
\hline \% of positives & 6.24 \\
\hline Total \# of Vaginal births & 768 \\
\hline \# of positive Vaginal & 70 \\
\hline $\begin{array}{l}\text { \% of positive Vaginal from total contaminated } \\
\text { samples }\end{array}$ & 9 \\
\hline \% of Positive vaginal from total population & 5.60 \\
\hline Total \# of C-section & 482 \\
\hline \# of positive C-section & 8 \\
\hline $\begin{array}{l}\text { \% of positive C-section from total contaminated } \\
\text { samples }\end{array}$ & 1.7 \\
\hline \% of positive C-section from total population & 0.64 \\
\hline
\end{tabular}

Table 2: Chi-square without Yates correction and P-value.

\begin{tabular}{|l|l|}
\hline Two-tailed P-value & $<0.0001$ \\
\hline $\begin{array}{l}\text { Chi-squared without Yates } \\
\text { correction }\end{array}$ & $\begin{array}{l}25.32 \text { with 1 degrees of } \\
\text { freedom }\end{array}$ \\
\hline
\end{tabular}




\section{$\%$ from positive samples}

$\%$ of Vaginal from total positive $\quad \square \%$ of C-section from total positive

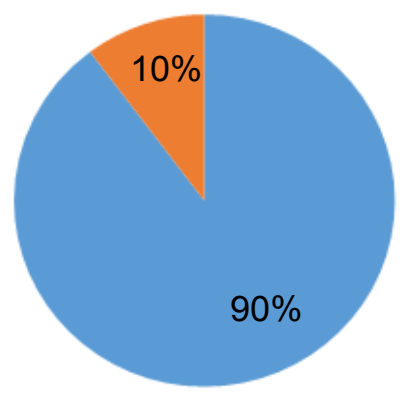

Figure 1: Percentage of contaminations in vaginal delivery compared to C-section delivery.

\section{Infection Rates \\ C-section and Vaginal Deliveries}

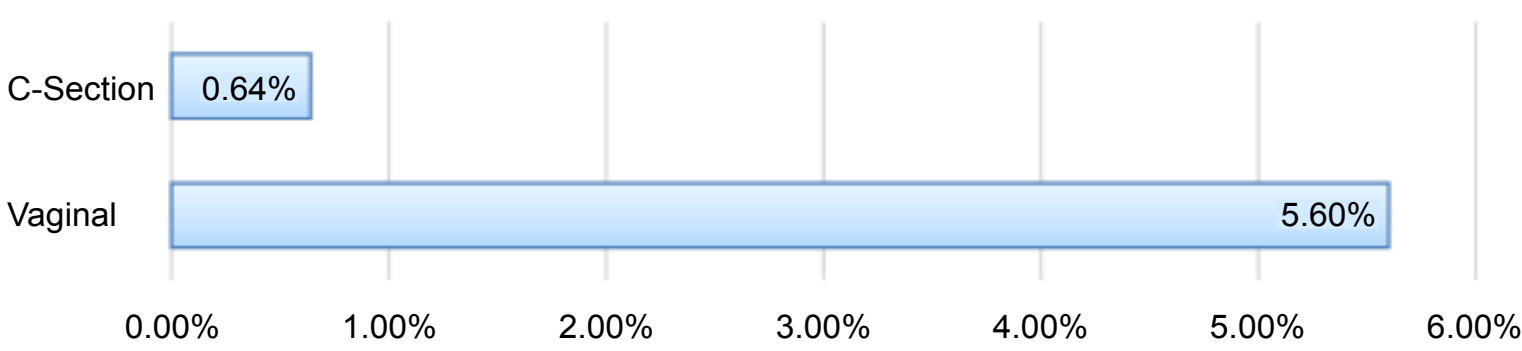

Figure 2: Infection rates of $\mathrm{C}$-section and Vaginal deliveries.

Table 3: Bacterial organisms in Vaginal and C-section deliveries.

\begin{tabular}{|l|l|l|}
\hline C-Section $\mathbf{N =}$ & 19 & \\
\hline Vaginal $\mathbf{N}=$ & 108 & $\%$ of Positive \\
\hline (Vaginal) Aerobic only & \# of positive samples & 30 \\
\hline Escherichia coli & 32 & 6 \\
\hline Staphylococcus epidermidis & 7 & 5 \\
\hline Enterococcus faecalis & 5 & 4 \\
\hline Staphylococcus hominis & 4 & 4 \\
\hline Gram Positive Bacilli (Diptheroids) & 4 & $\%$ of Positive \\
\hline (C-section) & $\#$ of positive samples & 26 \\
\hline Escherichia coli & 5 & 11 \\
\hline Staphylococcus epidermidis & 2 & 11 \\
\hline Klebsiella pneumoniae & 2 & 11 \\
\hline Staphylococcus hominis & 2 & 11 \\
\hline Coagulase negative Staphylococcus species & 2 & \\
\hline
\end{tabular}

test and Chi-squared two-tailed P-value of less than 0.0001 (Table 2).

\section{Bacterial Organism's Distribution among Emir- ates and GCC Countries}

A retrospective data was taken from 2011-2014 to gather more information regarding the type of bacterial organism present in C-Section and Vaginal collection methods. Among the 4-year period there were a total of 127 positive samples were analyzed, 19 positive samples were $\mathrm{C}$-section and 108 samples were vaginal delivery. 
From the data it shows the frequency of the bacterial organism and number of contaminations we can see that Escherichia coli is the most frequent organism in both C-section 26\% and Vaginal 30\% deliveries followed by Staphylococcus epidermidis

\section{Frequency of bacterial organisms identified}

Table 3.

\section{Discussion}

\section{Principal findings}

The result from the historical data analysis shows the substantial cases of bacterial contamination of the umbilical blood. Major contamination is caused due to the bacteria E. coli followed by the Staphylococcus epidermidis $6 \%$ and Enterococcus faecalis $5 \%$ in Vaginal cord blood collection method.

\section{Results}

For the data of 2014 we can see that vaginal collection contamination rate is $6 \%$ while C-section contamination rate is only $1 \%$. Hence, the $\mathrm{C}$-section delivery has 6 times less contamination rates than vaginal delivery.

\section{Clinical implications}

Reducing bacterial contamination can be achieved by:

1) Standardizing a general sterility procedure

2) Collection of cord blood should be performed after the delivery of the infant but before delivery of the placenta using a closed collection system and procedures that minimize risk of bacterial and maternal fluid contamination [2]

3) Birth unit staff should receive training in standardized cord blood collection procedures that optimize cord blood unit volume and reduce the rejection rate owing to labeling problems, bacterial contamination, and clotting [1].

\section{Research implications}

Cord blood collection techniques must be improved in all the countries. Therefore, sterile techniques must be implemented and standardized between all countries.

\section{Conclusion}

The analysis results clearly show that the delivery method has an impact on the bacterial contamination rate of the umbilical cord blood. The $\mathrm{C}$-section bacterial contamination rate is very low compared to the vaginal bacterial contamination rate for samples received in our lab from UAE and GCC.

The delivery method had no impact on the sample weight, viability, total CD34, and post TNC count.

\section{Data Availability}

The raw data used to support the findings of this study are available from the corresponding author upon request.

\section{Conflict of Interest}

The author reports no conflict of interest or funding sources.

\section{Authors' Contributions}

Mai Ibrahim, Sarah Al-Hajali, Mona Abdelmeguid and Saad Aswad contributed equally to this article.

\section{Acknowledgments}

A poster for this work was presented and the presentation of the manuscript was included in "Cord Blood Connect Meeting Abstracts (Stem Cells Translational Medicine).

\section{References}

1. Ballen KK, Gluckman E, Broxmeyer HE (2013) Umbilical cord blood transplantation: The first 25 years and beyond. Blood 122: 491-498.

2. Clark P, Trickett A, Stark D, Vowels M (2012) Factors affecting microbial contamination rate of cord blood collected for transplantation. Transfusion 52: 1770-1777.

3. (2015) NetCord, Foundation for the Accreditation of Cell Therapy (FACT). NetCord-FACT international standards for cord blood collection, banking, and release for administration accreditation manual $6^{\text {th }}$ edition.

4. Matijević R, Erjavec K (2016) Knowledge and attitudes among pregnant women and maternity staff about umbilical cord blood banking. Transfus Med 26: 462-466.

5. McGuckin CP, Forraz N, Baradez MO, Navran S, Zhao J, et al. (2005) Production of stem cells with embryonic characteristics from human umbilical cord blood. Cell Prolif 38: 245-255.

6. McGuckin CP, Forraz N, Allouard Q, Pettengell R (2004) Umbilical cord blood stem cells can expand hematopoietic and neuroglial progenitors in vitro. Exp Cell Res 295: 350359.

7. Rogers I, Yamanaka N, Bielecki R, Wong CJ, Chua S, et al. (2007) Identification and analysis of in vitro cultured CD45-positive cells capable of multi-lineage differentiation. Exp Cell Res 313: 1839-1852.

8. Ballen K, Verter KF, Kurtzberg J (2015) Umbilical cord blood donation: Public or private? Bone Marrow Transplant 50: 1271-1278.

9. Lasky LC, Lane TA, Miller JP, Lindgren B, Patterson HA, et al. (2002) In utero or ex utero cord blood collection: which is better? Transfusion 42: 1261-1267.

10. Chan (2009) Umbilical Cord Blood for Transplantation: From Collection Quality to Its Use in Cerebral Palsy. Hong Kong J Gynaecol Obstet Midwifery 9: 43-48

11. Brecher (2005) Bacterial contamination of blood components. Clin Microbiol Rev 18: 195-204. 